\title{
GRAMÁTICAS DE LA PUBLICIDAD SOBRE VIOLENCIA: LA AUSENCIA DEL EMPODERAMIENTO TRAS EL OJO MORADO Y LA SONRISA SERENA
}

\author{
DIANA FERNÁNDEZ ROMERO \\ Universidad Rey Juan Carlos (Madrid)
}

\section{INTRODUCCIÓN}

Las representaciones tanto de la mujer como de la violencia de género en la publicidad de las instituciones en España acerca de este problema ha experimentado un cambio significativo desde que comenzaron a difundirse campañas a través de los medios de comunicación en los años noventa del siglo pasado hasta la actualidad. La transformación de imágenes y eslóganes ha ido pareja, y la tendencia general ha sido hacia una progresiva desdramatización y a la emisión de mensajes en positivo.

En lo que se refiere a la representación visual y a los textos verbales, es significativo evidenciar cómo en un principio las campañas estaban más relacionadas con la violencia física y trataban, sobre todo, de incitar a las mujeres a denunciar a través de lemas e imágenes impactantes. Es el caso de anuncios como el que lanzó el Instituto de la Mujer en 2001 bajo el lema «Si te quedas sin palabras te quedarás sin nada. Recupera tu vida. Habla». En la imagen, destacaba el rostro de una mujer con los ojos llorosos y amoratados junto a un teléfono a través del cual era incapaz de hablar.

Tan sólo un año después, esta misma institución difundió una campaña en la que cambiaba manifiestamente el enfoque. En este caso se recurría a la figura de distintas mujeres, algunas de ellas famosas, con semblantes amables y optimistas, que proyectaban un mensaje esperanzador y de respaldo: "Tú no eres la culpable, contra la violencia doméstica no estás sola».

Se abría así el camino hacia campañas como la más próxima de la Consejería de Empleo y Mujer de la Comunidad de Madrid ${ }^{1}$, que para la puesta en escena

1. La Comunidad de Madrid lanzó una campaña en abril de 2006 con el mensaje "Contra la violencia de género, vamos en serio» que publicitaba el teléfono de atención 012. Uno de sus anuncios volvió a emitirse en televisión a finales de 2007. 
utiliza los testimonios de dos supuestas víctimas que han salido de la espiral de violencia y que con una sonrisa serena animan a otras mujeres a que denuncien.

A pesar de estos cambios, y buceando en los textos-discursos publicitarios ${ }^{2}$, surge la cuestión: ‘han cambiado realmente sus tópicos, sus temas, sus asuntos ${ }^{3}$ ? Para contestar a esta pregunta, en este artículo atenderemos a la estructura profunda de estos textos desde una dimensión transfrástica -es decir, que atienda al texto, y no a la frase-, lo que aquí vamos a dar en llamar sus gramáticas ${ }^{4}$.

En este marco, el primer planteamiento que queremos hacer es si el discurso institucional, que trasciende, entre otras vías, por medio de estas campañas -pues un texto siempre alude a y se conecta con otros textos, y por lo tanto la publicidad induce a hacer paráfrasis y asociaciones con otros textos de las administraciones ${ }^{5}$-, fue y sigue siendo, a pesar del cambio de apariencias, sobre todo de protección y refugio hacia las mujeres; y si mantiene la premisa, para poder prestar la asistencia, de que ellas den el paso previo de denunciar sin alertarlas de las verdaderas consecuencias que esa decisión puede ocasionarles 6 . Nos conduce a pensar que esto es así la más reciente publicidad impulsada por la Delegación Especial del Gobierno para la Violencia de Género ${ }^{7}$, cuyo anuncio en televisión, emitido en los tres últimos meses de 2007 y en marzo de 2008 para dar a conocer el teléfono $016^{8}$, incluyó lemas como: «Tranquila, te vamos a ayudar» o "A la primera señal de malos tratos, llama». Pero trataremos de demostrarlo más ampliamente en adelante.

2. Vamos a utilizar indistintamente la doble terminología que ofrece la semiótica de texto y discurso para abordar el análisis de los anuncios publicitarios objeto de estudio. En este sentido, concebimos el discurso como "proceso semiótico», tal y como lo entienden LOZANO, Jorge, et al: Análisis del discurso. Hacia una semiótica de la interacción textual, Madrid, Cátedra, 1999, p. 34 . Y el texto como "no autista», ya que incluye al destinatario; "hecho social y cultural», pues construye su significado en relación a un contexto; "productivo", en el sentido de que pretende cambiar algo; "proceso interactivo", pues marca una actitud del enunciador y establece un tipo de relación con el destinatario; y creador de una red que se ubica con otras redes, según lo comprende Cristina Peñamarín en "¿Qué puede mostrar el análisis de textos? Discursos e imágenes sobre la inmigración en El País», Cuadernos de Información y Comunicación, 3 (1997), pp. 146-148.

3. En el estudio sobre la coherencia de la estructura profunda del texto, van Dijk concibe la macroestructura como la estructura abstracta subyacente o forma lógica de un texto, y considera que las macroestructuras semánticas son la reconstrucción teórica de nociones como tópico, tema o asunto del discurso. LOZANO, Jorge, et al: Op. cit., pp. 23-26.

4. En alusión a la gramática del texto que se constituyó con el paso en la teoría semiótica de la frase al texto como centro -a diferencia de la lingüística frástica-, y de la que es representante, entre otros, van Dijk. LOZANO, Jorge, et al: Op. cit., p. 36.

5. PeÑAmaRín, Cristina: «¿Qué puede mostrar...», op. cit., p. 148.

6. Como el hecho de tener que volver a su domicilio y convivir con el maltratador hasta que se adopten las medidas pertinentes.

7. Organismo dependiente de la Secretaría General de Políticas de Igualdad del Ministerio de Trabajo y Asuntos Sociales, creado por la Ley de Medidas de Protección Integral contra la Violencia de Género. En abril de 2008 pasó a denominarse Delegación del Gobierno para la Violación de Género y a depender del Ministerio de Igualdad.

8. El Ministerio de Trabajo y Asuntos Sociales puso en marcha en octubre de 2007 este nuevo número telefónico de información y asesoramiento jurídico en materia de violencia de género en cumplimiento de un Catálogo de Medidas Urgentes aprobado el 15 de diciembre de 2006. 
Gramáticas de la publicidad sobre violencia: la ausencia del empoderamiento tras...

Otra premisa que vamos a defender aquí es que la representación de la violencia en estos discursos está, paradójicamente, ejerciendo violencia simbólica, la que Pierre Bourdieu define como

«violencia amortiguada, insensible, e invisible para sus propias víctimas, que se ejerce esencialmente a través de los caminos puramente simbólicos de la comunicación y del conocimiento o, más exactamente, del desconocimiento, del reconocimiento o, en último término, del sentimiento» ${ }^{9}$.

La victimización de las mujeres que sufren malos tratos, que según trataremos de verificar puede desencadenarse a través de ese tratamiento asistencialista y protector que les confieren las instituciones a través de las campañas, es, como exponen Navarro y Vega, una clara manifestación de esta violencia, que se da «en la comunicación y en la cultura, en la producción/circulación/recepción de representaciones» ${ }^{10}$.

Como tercera proposición, y partiendo de que «no sólo los sujetos producen los discursos, sino que también son un producto de ellos ${ }^{11}$, vamos a prestar atención a la representación que los textos dan de su destinador y su destinatario -que no emisor y receptor, pues no son realidades empíricas, sino construcciones textuales ${ }^{12}-$; y vamos a mantener que esas representaciones de la violencia generan un «nosotr@s»no maltratad@s -instituciones, medios, sociedad: asistentes anestesiados ante la repetición del shock del maltrato ${ }^{13}$-; y unas "otras", extrañas por diferentes, opacas por invisibles (sobre todo las que no reciben golpes físicos), víctimas vulnerables que tienen que denunciar, y a las cuales, más que potenciar su confianza e independencia, es preciso asistir y arropar.

También vamos a acercarnos a los estudios de la recepción para observar qué lectura de los textos realizan algunos de los receptores empíricos -esta vez en el marco de la realidad-, tratando de poner de manifiesto cómo hacen intervenir sus competencias culturales, sus formas de vida y de uso al enfrentarse con ellos ${ }^{14}$.

\section{PERSPECTIVA METODOLÓGICA}

El abordaje de estas cuestiones se llevará a cabo a partir de la siguiente perspectiva metodológica. Primeramente presentaremos la publicidad objeto de estudio. En este artículo nos vamos a centrar en las campañas institucionales que se han puesto en marcha a nivel estatal desde 1998 hasta la actualidad por parte del Instituto de la Mujer primero, y del Ministerio de Presidencia y la De-

9. BouRdieu, Pierre: La dominación masculina, Barcelona, Anagrama, 2007, p. 12.

10. NAVARro, Amparo y VegA, Cristina: Mediaciones y traslaciones. Gramáticas visuales de la violencia machista en la universidad, Madrid, Traficantes de sueños, 2007, p. 13.

11. LOZANO, Jorge, et al: Op. cit., p. 89.

12. Ibíd., p. 113.

13. Ante la proliferación de noticias sobre asesinatos que se narran en clave de sucesos y conllevan un recuento continuado de las víctimas.

14. Peñamarín, Cristina: "¿Qué puede mostrar...», op. cit., p. 148. 
legación Especial del Gobierno para la Violencia después; así como en la última campaña de ámbito regional divulgada por la Comunidad de Madrid.

En todas ellas queremos observar cómo se representan la mujer y la violencia, a qué tópicos se recurre, qué escenificaciones y personajes estereotipados se utilizan ${ }^{15}$, y cómo este tipo de textos incorporan a sus destinatarios ${ }^{16}$-generando una identidad de las principales afectadas, las mujeres maltratadas, de tal forma que dan una imagen de éstas a la sociedad y hacen que se formen determinadas concepciones de ellas mismas a partir de las imágenes sociales que circulan sobre ellas ${ }^{17}$; así como de las instituciones, de los medios y del resto de la sociedad.

Después, dialogaremos con estos textos publicitarios, confrontando los mensajes de las campañas con los planes de la administración que las impulsan y observando que, según el planteamiento que realicen las instituciones en estos programas sobre el origen de la violencia contra las mujeres, se obtendrá una representación diferente del problema y se impulsarán medidas determinadas. En este caso estaremos muy pendientes de qué tipo de disposiciones se promueven, y si tienen que ver más con la asistencialidad o con el empoderamiento ${ }^{18}$.

Por último, como dijimos, atenderemos a los planteamientos de algunos de los receptores reales de esta publicidad para observar cómo la perciben determinadas mujeres que son el principal target de las campañas y cuáles son las opiniones de varios jóvenes que las ven desde la distancia.

Por un lado, analizaremos los discursos extraídos de 20 entrevistas abiertas semidirectivas ${ }^{19}$ a mujeres que tenían en común haber sufrido o seguir sufriendo violencia por parte de sus parejas o ex parejas y haber acudido a una institución para poner fin a su problema ${ }^{20}$. Por otro, prestaremos atención a los que

15. Como también veremos más adelante, Erving Goffman expone que estos son recursos empleados por la publicidad, los gobiernos y las organizaciones para transmitir sus mensajes. GOFFMAN, Erving: «La ritualización de la feminidad», en E. Goffman: Los momentos y sus hombres, Barcelona, Paidós, 1991, p. 143.

16. Peñamarín, Cristina: «Ficción televisiva y pensamiento narrativo», Semiosfera, 11 (2002). www. uc3m.es/uc3m/inst/MU/Cristin4.htm.

17. Lo que el interaccionismo simbólico ha dado en llamar el otro generalizado. RODRIGO ALSINA, Miquel: Teorías de la comunicación. Ámbitos, métodos y perspectivas, Barcelona, Castelló de la Plana, València, U. Autònoma de Barcelona, U. Jaume I, U. Pompeu Fabra, U. de València, 2001. El autor se plantea como ejemplo qué imagen de sí mismos pueden tener los inmigrantes cuando la sociedad receptora los denomina «los ilegales» (pp. 168-169).

18. Entendemos aquí el término empoderamiento como proceso de cambio que implica: que las mujeres tomen conciencia sobre su subordinación y el aumento de la confianza en sí mismas; la organización autónoma para decidir sobre sus vidas y la movilización para identificar sus intereses; y transformar las relaciones, estructuras e instituciones que las limitan y perpetúan su situación. Según los planteamientos del Diccionario de Acción Humanitaria y Cooperación al Desarrollo. http://dicc.hegoa.efaber.net

19. De acuerdo con la terminología propuesta en VALLES, Miguel: Técnicas cualitativas de investigación social. Reflexión metodológica y práctica profesional, Madrid, Síntesis, 1999, p. 184.

20. Las entrevistas, que forman parte de una investigación más amplia, han sido realizadas entre los años 2001 y 2008 a informantes con diferentes perfiles socioculturales. Se buscó la homogeneidad en cuanto al sexo (mujeres) y al hecho de que todas fueran o hubiesen sido maltratadas 
recogimos en 25 entrevistas estandarizadas abiertas ${ }^{21}$ a jóvenes universitarios estudiantes de primer curso de Periodismo, con edades comprendidas entre los 18 y los 21 años, que respondieron a un listado de preguntas ordenadas y redactadas por igual con respuesta libre sobre las campañas que son aquí objeto de estudio y que previamente visionaron.

Con estas aportaciones pretendemos contribuir a la escasa reflexión sobre las representaciones de las mujeres y la violencia de género en la publicidad institucional sobre este problema; poner de manifiesto los tópicos más recurrentes en esas campañas a lo largo de los últimos años y evidenciar los cambios; observar cuáles son las representaciones de destinador y destinatario y ver qué efectos generan; y dar voz a una representación de la audiencia -mujeres maltratadas y jóvenes universitarios, receptores reales- alumbrando así una parte fundamental del proceso comunicativo: la recepción.

\section{ESTADO DE LA CUESTIÓN}

En un artículo sobre la violencia de las representaciones, Peñamarín ${ }^{22}$ distingue diferentes líneas de investigación en esta esfera. Por un lado, la que indaga acerca de las representaciones de la violencia, en la que se inscribe, entre otras, la obra de Susan Sontag Regarding the pain of others sobre las imágenes de la guerra y la desgracia humanas. Por otro lado, alude a las perspectivas que se preocupan por la violencia que se genera en los medios o en los videojuegos ${ }^{23}$; o la violencia de la discriminación y la negación del otro ${ }^{24}$. La autora expone por último la dimensión que atiende a la violencia inscrita en el discurso «en el que se busca crear la comunidad de un 'nosotros' fuerte y cohesionado", de la que es buen ejemplo su escrito ${ }^{25}$. Es precisamente en estos dos últimos recintos de la relación sobre violencia y representación en los que queremos situar nuestro análisis.

En lo que atañe a la representación de la violencia de género en la publicidad encontramos numerosos estudios que sin embargo no se centran tanto en este ámbito como en las prácticas que se llevan a cabo en los medios de comunicación y que pueden extrapolarse a los anuncios. Es revelador el trabajo de Pilar

y que estuviesen en contacto con la administración. En la mayoría de los casos vieron la publicidad previamente a las entrevistas -algunas de ellas se negaron-, que ha ido incrementándose según han ido surgiendo nuevas campañas.

21. Según la clasificación de Patton sobre las variaciones de la entrevista cualitativa en VALLES, Miguel: Op. cit., p. 180.

22. Peñamarín, Cristina: "La violencia en las representaciones. Políticas de la indiferencia y la hostilidad», en F. García Selgas y C. Romero Bachiller (eds.): El doble filo de la navaja: violencia y representación, Madrid, Trotta, 2006, pp. 131-144.

23. En este ámbito podemos situar relevantes estudios como los siguientes: IMBERT, Gérard: Los escenarios de la violencia, Barcelona, Icaria, 1992; BOURDIEU, Pierre: Sobre la televisión, Barcelona, Anagrama, 1997; TISSERON, Serge: Internet, videojuegos, televisión, Barcelona, Editorial Grao, 2006.

24. A este propósito, se puede consultar el artículo de IRANZO, Patricia I.,: «Estereotipos publicitarios y violencia racial», Trípodos, número extra (2003), pp. 705-718.

25. Peñamarín, Cristina: «La violencia en...», op. cit. 
López Díez ${ }^{26}$ que repasa el tratamiento de la violencia masculina contra las mujeres en los medios españoles e invita a reflexionar sobre la imagen que se construye de la victimización de las agredidas y las asesinadas: «debemos dejar de hablar de que ha habido sesenta mujeres víctimas de la violencia doméstica y referirnos a sesenta hombres violentos que han acabado con la vida de otras tantas mujeres ${ }^{27}$.

En la misma dirección también es útil el manual de recomendaciones para reformular noticias sobre violencia contra las mujeres de Eulàlia Lledón ${ }^{28}$ publicado por el Instituto Andaluz de la Mujer. Algunos de los hallazgos que aquí nos interesan de la amplia investigación de Lledó sobre el tratamiento de la prensa en los medios andaluces que dio lugar al citado manual -no todos vieron la luz entonces- son destacados por Mercedes Bengoechea ${ }^{29}$. Por ejemplo, «la tendencia de la prensa (probablemente bienintencionada) de hablar siempre de las mujeres agredidas como seres pasivos, incluso si la noticia se hace eco de cómo algunas mujeres han ideado y puesto en funcionamiento estratagemas para acabar con su situación $»^{30}$.

Otro ámbito cuyo estado de la cuestión nos compete explorar es el de la representación de la mujer en el terreno de la publicidad. En lo tocante a esta relación hay una amplia bibliografía que hace hincapié sobre todo en la perpetuación de los estereotipos de madre, esposa y ama de casa o el de mujer objeto; y su contraste con la figuración que en los anuncios se ofrece del hombre, que sigue siendo el prototipo del conocimiento y de la autoridad: «De los hombres la mente y de las mujeres el cuerpo", manifiesta Elvira Altés ${ }^{31}$ aludiendo a uno de los modelos que encuentra Martín Serrano en su estudio sobre los estereotipos en televisión ${ }^{32}$. En este campo es reseñable el análisis que realizan Peñamarín y Fabretti sobre la mujer en la publicidad ${ }^{33}$ en el que abundan en la idea de que esta práctica cultural organiza todo un programa de perpetuación de los modelos dicotomizados de hombre sujeto frente al mundo y mujer pasiva unida a la naturaleza. Y esto es así, exponen, a pesar de que la imagen ideal que quieren

26. LÓPEZ DíEZ, Pilar: «La violencia contra las mujeres en los medios de comunicación», en P. López Díez: Mujer, violencia y medios de comunicación, Madrid, Instituto Oficial de RTVE, Ministerio de Trabajo y Asuntos Sociales, 2002, pp. 21-34.

27. López Díez, Pilar: Op. cit., p. 32.

28. LlEDó, Eulàlia: Cómo tratar bien a los malos tratos, Sevilla, Instituto Andaluz de la Mujer, 1999.

29. BENGOECHEA, Mercedes: "En el umbral de un nuevo discurso periodístico sobre violencia y agencia femenina: de la crónica de sucesos a la reseña literaria», Cuadernos de Información y Comunicación, 5 (2000), pp. 9-11.

30. BenGOECHEA, Mercedes: Op. cit., p. 9.

31. AltÉs, Elvira: «¿Cómo funcionan y para que sirven los estereotipos en los medios de comunicación?», www.bizkaia.net/Home2/Archivos/DPTO1/Noticias/Adjuntos/297_mujeres.jornadas03.Ponencias.doc.

32. Martín Serrano, Manuel: Nosotras y vosotros según nos ve la televisión, Madrid, Instituto de la Mujer, 1995, p. 77.

33. PeñAmARÍn, Cristina y FABRetTI, Carlo: La mujer en la publicidad, Madrid, Instituto de la Mujer, 1990 , p. 28. 
las mujeres para sí mismas no es la de la fémina bien casada o emparejada, sino la de que es autónoma, respetada y valorada por su trabajo.

En su publicación sobre los efectos de la publicidad, José Luís León ${ }^{34}$ recoge los tres ámbitos que han contemplado los women's studies que articulan la imagen publicitaria de la mujer: la publicidad estereotípica, que asigna roles predeterminados al hombre y la mujer; la publicidad de idealización de la belleza femenina; y la publicidad de cosificación sexual de la mujer.

Desde el ámbito institucional es relevante el trabajo del Observatorio de la Imagen de las Mujeres gestionado por el Instituto de la Mujer desde 1994, que realiza anualmente, por iniciativa propia y a través de las quejas ciudadanas, un seguimiento y análisis de la publicidad y de los contenidos de los medios de comunicación que tienen un tratamiento discriminatorio hacia las mujeres. En su informe más reciente ${ }^{35}$, fechado en 2006 , se constata que las modificaciones impulsadas por la Ley Integral contra la violencia de género en la Ley General de Publicidad ${ }^{36}$, promovieron que el órgano de autorregulación publicitaria - Autocontrol- dispusiera de mejores criterios para admitir y resolver las denuncias contra anuncios por discriminación de género. «Esta labor de sensibilización está contribuyendo a modificar las estrategias de comunicación de algunos anunciantes, principalmente de productos relacionados con el hogar», reza el informe. "Sin embargo", añade, "se constata también que la explotación del cuerpo femenino como un objeto permanece e, incluso, se incrementa».

En 1998 nace la Comisión Asesora de Publicidad no Sexista Begira ${ }^{37}$, cuyo principal cometido es crear una conciencia crítica en la ciudadanía respecto a la publicidad sexista o estimular la creación de un tipo de publicidad que refleje a mujeres y hombres en papeles diversificados ${ }^{38}$.

Sobre la representación de la violencia contra la mujer en la publicidad de la administración no encontramos excesivas investigaciones. Desde fuera de las instituciones existen referencias en algunos análisis que sin embargo no se centran exclusivamente en este asunto: es el caso del artículo de Inmaculada Martínez ${ }^{39}$, que en un estudio general sobre la mujer y la publicidad en España

34. León, José Luis: Los efectos de la publicidad, Barcelona, Ariel, 1996, p. 211.

35. Informe 2006 del Observatorio de la Publicidad Sexista del Instituto de la Mujer. Disponible en: http://www.mtas.es/mujer/medios/publicidad/observatorio.htm.

36. Ley 34/1988, de 11 de noviembre, General de Publicidad. Se modificó, entre otros, el artículo 3 , letra a, especificando que serán ilícitos «los anuncios que presenten a las mujeres de forma vejatoria, bien utilizando particular y directamente su cuerpo o partes del mismo como mero objeto desvinculado del producto que se pretende promocionar, bien su imagen asociada a comportamientos estereotipados que vulneren los fundamentos de nuestro ordenamiento coadyuvando a generar la violencia a que se refiere la Ley Orgánica de medidas de protección integral contra la violencia de género».

37. En el marco del II Plan de Acción Positiva para las Mujeres en la Comunidad Autónoma de Euskadi (PAPME).

38. JUARISTI, P.: "Origen, recorrido y futuro de la comisión asesora de publicidad no sexista y género. Begira»: www.bizkaia.net/Home2/Archivos/DPTO1/Noticias/Adjuntos/297_mujeres. jornadas03.Ponencias.doc, pp. 34-35.

39. MARTínEZ, Inmaculada: «La mujer y la publicidad en España: contradicciones sociales y discursivas», en www.razonypalabra.org.mx/libros/libros/mujerypublicidad.pdf, p. 19. 
se detiene brevemente a analizar una campaña del Ministerio de Trabajo y Asuntos Sociales en cuyo texto detecta «uno de los pocos y claros ejemplos de integración de la situación contradictoria de la mujer en cuanto al par mujer víctima/mujer heroína» ${ }^{40}$.

Entre los escasos trabajos impulsados por la administración resulta relevante el Informe Anual del Observatorio Estatal de Violencia contra la Mujer de $2007^{41}$ elaborado por un grupo de personas expertas coordinadas por Mercedes Bengoechea ${ }^{42}$. En el apartado que dedica a evaluar las medidas de sensibilización, prevención y detección de la violencia llevadas a cabo en España en el año anterior, repara en la labor de las campañas de las instituciones y realiza algunas críticas y propuestas de mejora. El Informe estima que sería conveniente que las campañas dejasen de ser episódicas y se les diese mayor continuidad. Respecto a su contenido, el grupo de especialistas se percata de que «la mayoría de las desarrolladas en el ámbito público se dirigen a animar o convencer a la mujer de la conveniencia de denunciar y salir de la situación (a veces, de un polémico supuesto 'deber' de hacerlo)». Apunta que también se han puesto en marcha campañas "cuyo objetivo reside en persuadir a la ciudadanía de la imposibilidad de ser neutral y denunciar los casos de violencia de género conocidos». Pero alerta de que «ni uno ni otro tipo de campañas van siempre acompañadas de información pertinente» $y$ echa en falta más anuncios dirigidos específicamente a agresores que les hagan ver las consecuencias de sus acciones, y destinados a la sociedad "para que rechace a los perpetradores de violencia de género» ${ }^{43}$.

\section{DE GOLPES, MORETONES, TELÉFONOS Y SONRISAS}

\subsection{Los mensajes}

Como dijimos, los textos publicitarios de las instituciones sobre violencia contra las mujeres han experimentado variaciones en los últimos años. Para atender a esa trayectoria desde sus comienzos hasta ahora, en este apartado vamos a recoger los principales mensajes que se han empleado en las campañas objeto de estudio.

En el marco del I Plan de Acción contra la Violencia Doméstica, aprobado para el período 1998-2001, el Instituto de la Mujer impulsó tres campañas en años

40. En concreto, la autora hace referencia al anuncio del Instituto de la Mujer de 2002 con el lema "Contra los malos tratos no estás sola». Según Martínez, la integración de la contradicción no está en la iconografía -mujeres famosas que apoyan la causa - sino en el texto que trata a la mujer como víctima de los malos tratos y a su vez como heroína capaz de luchar y hacer frente a las situaciones más aberrantes. MARTínEZ, Inmaculada: Op. cit., p. 19.

41. Órgano colegiado interministerial creado por Real Decreto 253/2006, al que corresponde el asesoramiento, la evaluación, la colaboración institucional, la elaboración de informes y estudios y de propuestas de actuación en materia de violencia de género.

42. Informe anual del Observatorio Estatal de Violencia sobre la Mujer, Ministerio de Trabajo y Asuntos Sociales. Subdirección General de Información Administrativa y Publicaciones, Madrid, 2007. Disponible en: http://www.observatorioviolencia.org/upload_images/File/DOC1204104060_ InformeAnualInternet.pdf

43. Informe anual..., op. cit., p. 99. 
consecutivos. La primera de ellas, que se elaboró tras la aprobación del Plan, concluía con este mensaje: "Denunciemos los malos tratos. Siempre se puede volver a empezar». El objetivo, según nota de prensa, era el de concienciar a la sociedad sobre la necesidad de no permanecer al margen de este problema y dar a conocer su magnitud. Se publicitaba entonces el teléfono de atención gratuita 90019 10 10, que incrementó los servicios para atender las demandas relacionadas con la campaña.

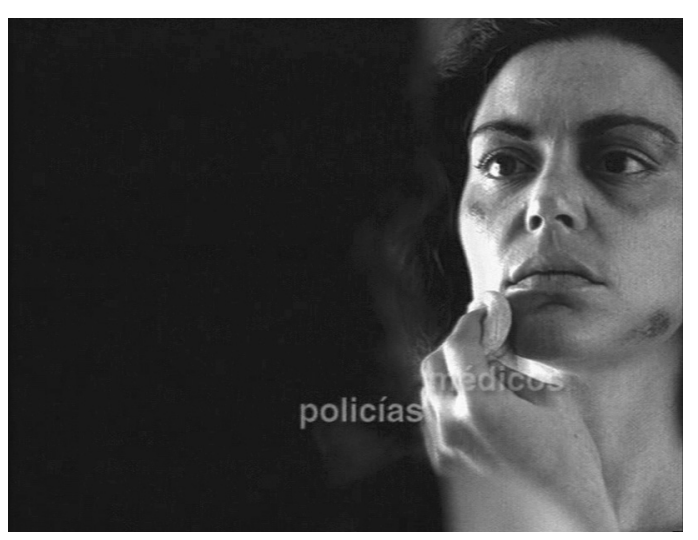

En 1999, el mensaje empleado fue: "Si ocultas la verdad nadie sabrá que necesitas ayuda. Que no te marque el miedo. Marca este teléfono". Junto al número gratuito, iban surgiendo en pantalla los servicios a disposición de las mujeres: psicólogos, médicos, policías, trabajadoras sociales, abogadas... Según difundió el Instituto de la Mujer, esta publicidad se centró en las mujeres víctimas, haciéndoles llegar un mensaje de apoyo e informándoles de los múltiples recursos sociales a los que podían acudir.

Un año después se emitió el anuncio "La violencia contra las mujeres nos duele a todos, nos duele a todas". Su objetivo era poner de manifiesto las consecuencias que la violencia produce no sólo en las víctimas sino también en sus hijos e hijas, y generar rechazo social hacia los agresores. También en este caso se anunciaba el teléfono del Instituto de la Mujer.

El II Plan Integral contra la Violencia Doméstica 2001-2004 favoreció la realización de dos campañas. Una en 2001

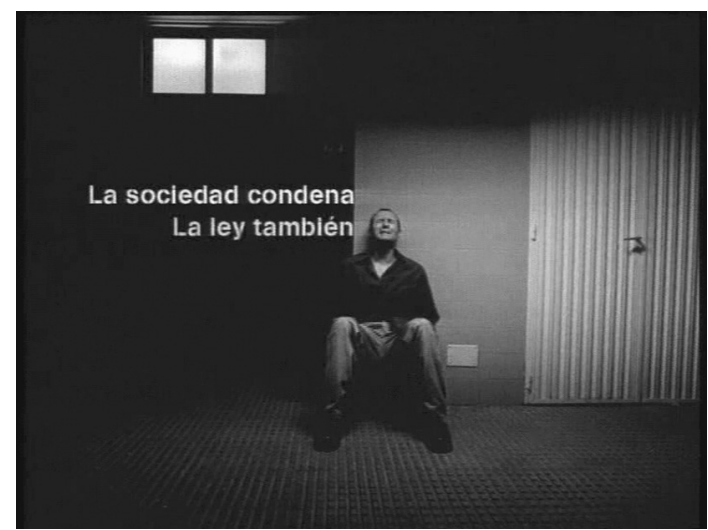



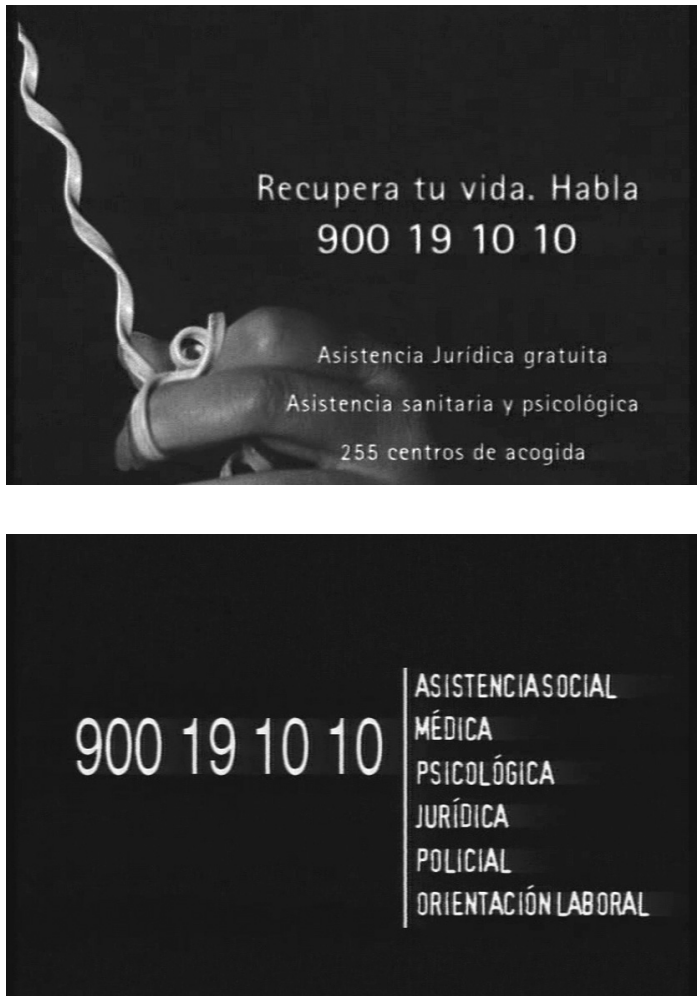

con el mensaje "Si te quedas sin palabras, te quedarás sin nada. Recupera tu vida. Habla", que surgió con la intención de facilitar a las mujeres información sobre las distintas ayudas que podían recibir (asistencia jurídica gratuita, sanitaria y psicológica, 225 centros de acogida...), así como de incrementar su confianza animándolas a romper el silencio y aislamiento en que se encuentran -siempre según nota del organismo-. Y un año después otra con el siguiente manifiesto que proclamaban once mujeres, algunas de ellas famosas: "Querida amiga, sé de tu dolor, sé de tu silencio. Estamos contigo. Porque tienes derechos, porque tienes dignidad. Porque hay otra vida. Contra los malos tratos, no estás sola». Al final, sobre la pantalla, se mostraban el teléfono y una serie de prestaciones: asistencia social, médica, psicológica, jurídica, policial y orientación laboral.

Después de la aprobación de la Ley Integral ${ }^{44}$, que impulsó un Plan $\mathrm{Na}$ cional de Sensibilización y Prevención ${ }^{45}$, este organismo ha puesto en marcha otras dos iniciativas. En 2006 produjo varios anuncios en colaboración con el Consejo Superior de Deportes y la Liga de Fútbol Profesional en los que Fernando Torres o Iker Casillas pronunciaban frases como "Ante la violencia de género, no podemos guardar silencio. Ayúdanos a erradicarla" o "Para ganar la competición más

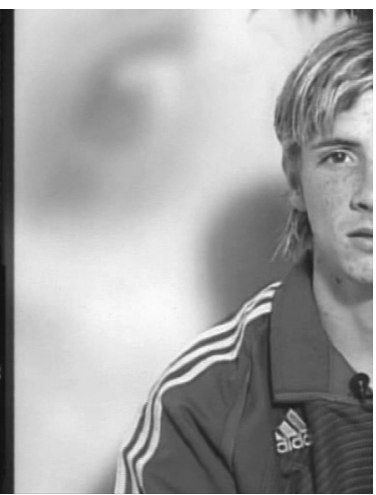

44. Ley Orgánica 1/2004, de 28 de diciembre, de Medidas de Protección Integral contra la Violencia de Género.

45. Este Plan se aprobó en el mes de diciembre de 2005 en Consejo de Ministros. 
importante es necesario el esfuerzo de toda la sociedad. Di no a la violencia contra las mujeres». Ese mismo año, en los meses de junio y julio, se difundió en radio la cuña "Antes» que relataba un caso de maltrato desde su final -la muerte-, hasta su inicio -el desprecio- "para alertar a las víctimas de un proceso que va en aumento», según informó EFE.

Más adelante, el Ministerio de Presidencia tomó el relevo del Instituto de la Mujer e impulsó, coincidiendo con la celebración del 25 de noviembre, Día Internacional de Lucha contra la Violencia sobre la Mujer y con el segundo aniversario de la aprobación de la Ley Integral, una campaña con tres spot que compartían eslogan: "Contra los malos tratos, gana la Ley». Se dirigía, por un lado, a las mujeres que sufren malos tratos para recordarles que cuentan

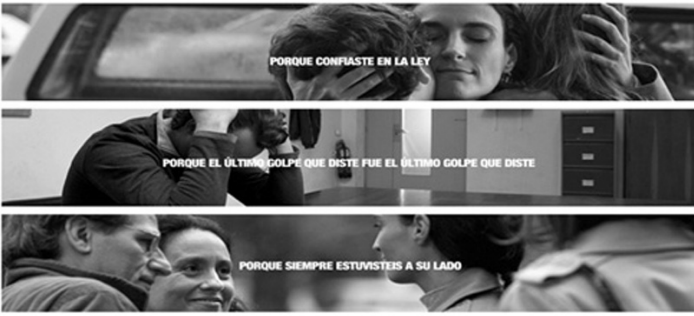

25 DE NOVIEMERE DLA INTERRACIONALL CONTRA LA VIOLENCAA DE GENERO

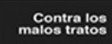

敞:

gana la ley

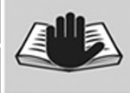
con el respaldo de una ley que les da amparo y protección, además de facilitarles medios para comenzar una nueva vida; por otro a los maltratadores, poniendo el acento en que están fuera de la norma; y finalmente a la sociedad, para fomentar su movilización.

La iniciativa más reciente, a la que hicimos

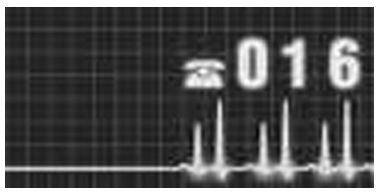
referencia también más arriba, es la campaña que anuncia la puesta en marcha de un nuevo teléfono de atención, el 016. A través de

este número, confidencial y gratuito, se ofrece información sobre recursos sociales y asesoramiento jurídico los 365 días del año.

A nivel regional, la Comunidad de Madrid emitió en 2006 y 2007 una campaña con el lema "Contra la violencia de género, vamos en serio. Llámanos al 012 $y$ pregunta por mujer». Mientras una voz en off pronunciaba estas palabras, iban surgiendo en pantalla los servicios disponibles: asistencia social, apoyo psicológico y orientación jurídica y laboral. El consejero de Mujer, Juan José Güemes, se expresaba así en su presentación: «las mujeres víctimas de la violencia de

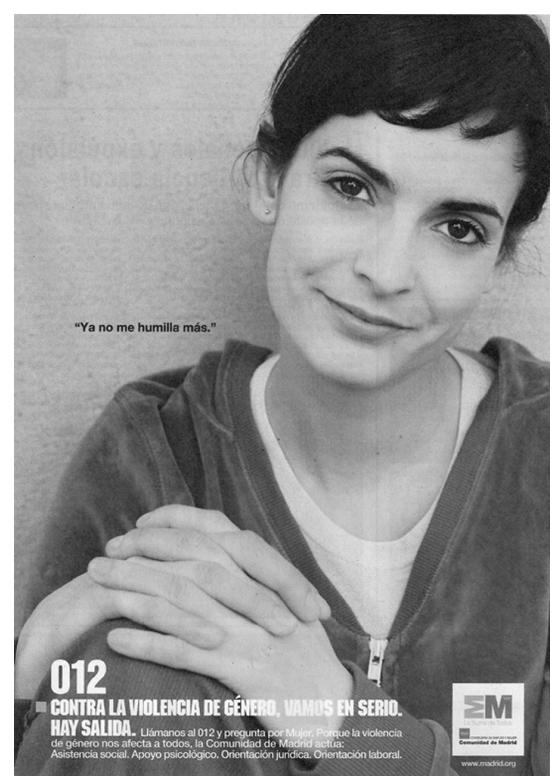


género tienen que saber que con la ayuda de todos -instituciones y sociedadhay salida ${ }^{46}$.

Este recorrido por los mensajes de las campañas que han circulado en el ámbito público en los últimos diez años nos lleva a concluir que las instituciones han utilizado mayoritariamente los spot para anunciar los recursos disponibles para las mujeres maltratadas -teléfonos, atención psicológica, jurídica, etc.- y para animarlas a que denuncien para poner fin a su situación, dejando fuera del discurso oficial la apuesta por su empoderamiento.

\subsection{Las imágenes}

Pero además de en los eslóganes, nos parece interesante detenernos en las iconografías que se utilizan en estos anuncios. De su análisis podemos concluir que en las escenificaciones que esta publicidad construye se detectan las ritualizaciones de segundo grado o hiperritualizaciones que reveló Goffman en su estudio sobre la imagen fotográfica de revistas y publicidad. El sociólogo canadiense observa que esas imágenes son «escenificaciones de escenificaciones, puesto que sus autores, para producirlas, se sirven forzosamente del 'idioma ritual' de la sociedad» ${ }^{47}$, un idioma que se compone de signos rituales destinados a facilitar la orientación mutua de los participantes en las interacciones cara a cara, que conformarían las ritualizaciones de primer grado.

Como dijimos, Goffman enumera una serie de métodos, como utilizar escenas y personajes estereotipados, los cuales no son sólo utilizados por los publicitarios, sino también por los gobiernos y las organizaciones de fin no lucrativo para transmitir sus mensajes ${ }^{48}$. Recursos que no son baladíes, pues a pesar de basarse en escenas ficticias, pueden conducir al auditorio a atribuir un sí mismo a los personajes representados $^{49}$.

¿Qué rituales se rescatan de los que se utilizan en sociedad y se escenifican -hiperritualizando- en estos anuncios? ¿Qué escenas y personajes estereotipados?

Las primeras campañas del Instituto de la Mujer sitúan la acción en el ámbito doméstico. Muchos elementos nos lo indican: pues algunas de las escenas se desarrollan en un dormitorio

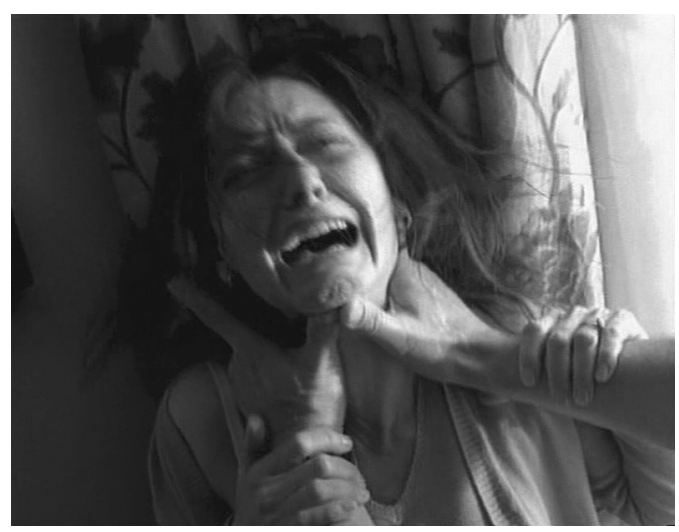

46. Según nota de prensa de la Comunidad de Madrid emitida el 7 de abril de 2006.

47. GOFFMAN, Erving: Los momentos y sus hombres..., op. cit., p. 135.

48. Ibíd., p. 143.

49. MUÑOZ, Blanca (coord): Medios de comunicación, mujeres y cambio cultural, Madrid, Dirección General de la Mujer, Comunidad de Madrid, 2001, p. 300. 


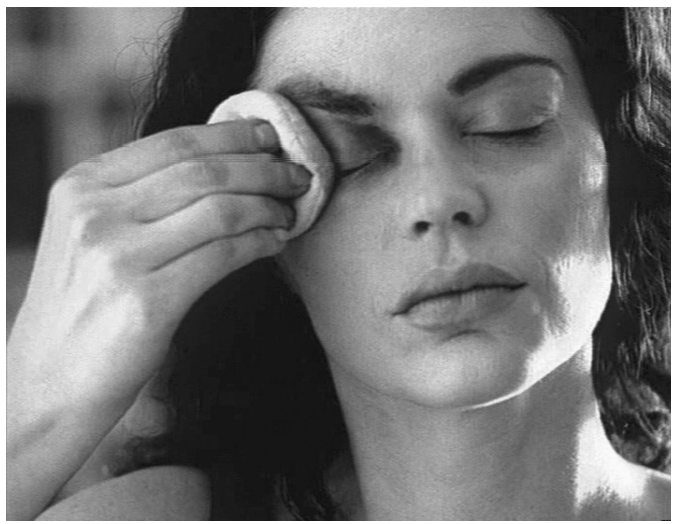

conyugal (en el primer anuncio, la cámara enfoca la fotografía de una pareja el día de su boda justo antes de mostrar el golpe de un hombre a su esposa que la tumba en la cama; en el segundo, una mujer se desmaquilla frente a la coqueta mientras el espejo le va devolviendo un rostro amoratado); y otras en la habitación de los juegos (en el spot en el que un niño consuela a su madre que está tirada en el suelo inmóvil con signos de haber recibido una paliza), o en la cocina (la escena de una mujer que intenta hablar por teléfono sin conseguirlo se ubica en este espacio).

En esta publicidad la protagonista se halla sola o en familia. Cuando se encuentra en soledad, es una mujer atormentada y desorientada que descubre los golpes ocultos tras la pintura o que, sollozando, trata de buscar ayuda a través del teléfono. En ambos casos no logra comunicar lo

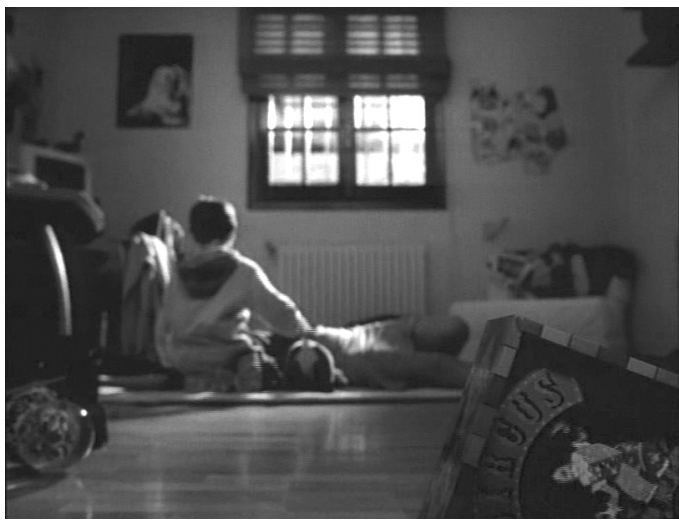
que le ocurre: es una voz en off masculina la que le indica que no oculte la verdad porque si no nadie sabrá que necesita ayuda, o que no tenga miedo y marque el número de teléfono; detrás de él habrá personas "que están aquí para protegerte y apoyar lo que tú decidas». Cuando aparece en familia, la mujer es esposa, pero también madre: que cuida de sus hijos y les ayuda en sus tareas, o que juega con ellos hasta que una paliza la deja inconsciente.

Las imágenes son mayoritariamente en blanco y negro o recurren a colores tenues, con la peculiaridad de que en todas las campañas los indicadores de los malos tratos físicos se destacan en color: en el primer spot del Instituto de la Mujer,

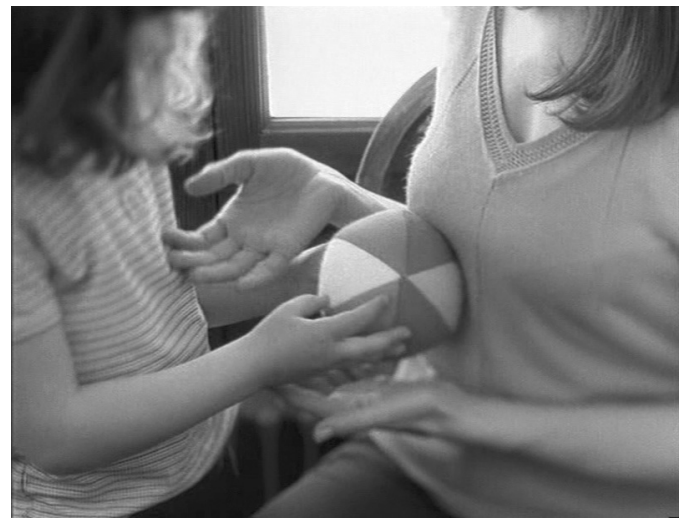


las escenas donde se producen agresiones contrastan por sus tonos vivos con el resto del anuncio, en el que predomina el tono sepia; en el tercero, sorprende el primer plano de una buena parte del rostro morado de la madre frente a la mano blanquecina de su hijo.

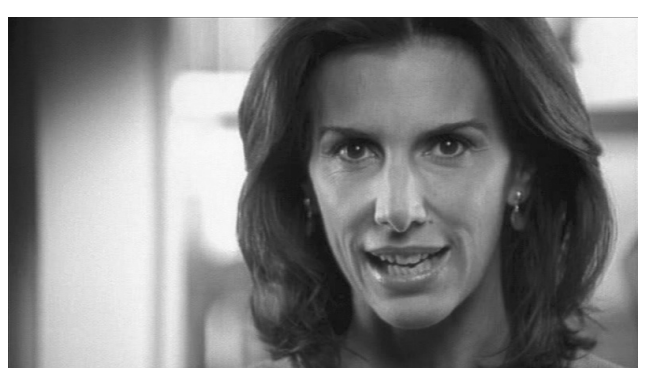

No obstante, las siguientes campañas, cuyos lemas describimos antes, suponen un giro en el ámbito de la representación visual. El anuncio de mujeres famosas utiliza colores vivos y escenarios no reconocibles, pues emplea primeros planos de las hablantes con fondos desenfocados. La publicidad sobre la Ley Integral nos permite acompañar a través de la cámara a una mujer en su recorrido desde que sale del juzgado con su abogada, hasta que se reencuentra con su familia, sus vecinos y sus hijos y regresa a su casa. A través de estampas en color, observamos que sus andares son firmes y que su gesto demuestra la satisfacción de haber denunciado.

Uno de los anuncios de la campaña de la Comunidad de Madrid recoge el testimonio de una mujer joven sentada en el suelo con un fondo de pared blanco, cuyos ojos se llenan de lágrimas cuando recuerda las humillaciones de su ex pareja, pero que sonríe resarcida y serena mientras explica que lo ha dejado y que ha rehecho su vida.

Tras esta exposición podemos señalar que en estas campañas se recurre a varios estereotipos. El más abundante es el que identifica a la maltratada con una mujer agredida físicamente, amoratada, perdida y atormentada. En estos casos es esposa y madre y el maltrato se produce en el domicilio conyugal. Asimismo, encontramos otra imagen recurrente, la de una mujer que sonríe porque sí ha sabido salir, que se siente satisfecha de haber roto con su verdugo y que saluda a una nueva vida con esperanza e ilusión. También es madre, pero ya no es esposa, sino "ex», y su marco de actuación no se limita solamente a su domicilio, el cual además ya no comparte con la pareja.

Estos textos también dibujan un perfil de las instituciones y del resto de la sociedad. Ésta, por ejemplo, estaría representada por las mujeres -famosas y desconocidas- que hablan a las maltratadas a través de la pantalla. Y las instituciones se manifiestan en el discurso publicitario por medio de los mensajes que remiten a los recursos que la administración pone a disposición de las mujeres que sufren violencia.

Pero si queremos seguir abundando en las gramáticas de estos anuncios y determinar si hay un verdadero cambio de tendencias, podemos observar si en ellos se produce la dinámica que nos descubre Greimas ${ }^{50}$ a propósito de la

50. GRANDI, Roberto: Texto y contexto en los medios de comunicación, Barcelona, Bosch, 1995, p. 87. 
publicidad social, la que aquí nos ocupa: el procedimiento que se adopta en este tipo de textos consiste en construir simulacros «negativos» que introduzcan en el destinatario cierta carga de "culpabilidad» en relación con determinado problema, respecto al que el sujeto comunicador se destaca como alguien dotado de competencia moral. Por lo que hemos advertido en estos anuncios, aunque el modelo de mujer cambie, finalmente termina siendo una víctima a la que la publicidad persuade de que la toma de decisiones está en sus manos, pero a la que a su vez previene de que son los sujetos comunicadores, las instituciones, los que las van a ayudar y orientar para poder salir.

\section{5. "¿TELEASISTENCIA DÍGAME? DENUNCIE»}

Para dialogar con los discursos presentados y seguir extrayendo conclusiones, vamos a servirnos de algunos de los planteamientos de un interesante estudio que trabaja con textos de instituciones políticas, sociedad civil y medios de comunicación de España y Europa sobre la (des)igualdad de género ${ }^{51}$. El análisis de las campañas puede enmarcarse en esta investigación pues muchos de los textos que se analizan en ella, como los referidos Planes contra la Violencia Doméstica o la Ley Integral, son la base para el desarrollo de la publicidad que aquí nos ocupa.

En el capítulo dedicado a la representación de la violencia de género ${ }^{52}$ encontramos observaciones sobre el caso español relevantes para nuestro análisis, como son que en la mayoría de los textos aparece la asistencia como objetivo clave; y que es frecuente la representación de las mujeres como víctimas que necesitan protección y asistencia ${ }^{53}$, o como las principales responsables de solucionar el problema de la violencia a través de sus denuncias ${ }^{54}$.

Nos interesa también el hallazgo de que, dependiendo de la respuesta que en esos textos se ofrezca a la pregunta sobre la causa o el origen de la violencia contra las mujeres, se obtendrá una representación del problema muy distinta $y$, por lo tanto, se ofrecerán diferentes soluciones al respecto.

«Es muy diferente si se identifica claramente el origen de la violencia en la desigualdad de las relaciones de género, que si se dejan sin explicar, o se hace de manera ambigua, las razones por las que son las mujeres las principales víctimas de este tipo de violencia, o si directamente se presenta el problema de la violencia doméstica como algo que puede ocurrir entre hombres y mujeres indistintamente de quién sea el agresor o quién la víctima» «5.

51. Bustelo, María y Lombardo, Emanuela (eds): Politicas de igualdad en España y en Europa, Madrid, Cátedra, 2007.

52. Bustelo, María; LóPez, Silvia y Platero, Raquel: «La representación de la violencia contra las mujeres como un asunto de género y un problema público en España», en M. Bustelo y E. Lombardo (eds): Op. cit.

53. Ibíd., p. 80.

54. Ibíd., p. 82

55. Ibíd., p. 73 
En función de esta clasificación, las autoras identifican tres marcos interpretativos fundamentales. El primero, llamado "De igualdad de género», contempla el fenómeno como un reflejo de las relaciones desiguales de poder dentro de la familia y en la sociedad; el segundo, denominado "Violencia doméstica con acento en las mujeres como principal grupo víctima», habla de esta violencia como un asunto frecuente pero no necesariamente relacionado con un problema entre hombres y mujeres ${ }^{56}$; y el tercero, calificado como "Violencia doméstica sin género", establece que víctimas y agresores no tienen ni sexo ni género y presenta el problema en términos neutrales ${ }^{57}$.

Cuando se refiere a las soluciones, el estudio remarca que una de las características del marco más relacionado con el género -el expuesto en primer lugar-es que en él, a diferencia de en los otros dos marcos, "se puede encontrar más claramente, aunque no siempre, un componente de empoderamiento de las mujeres víctimas y no sólo de tratamiento de los síntomas» ${ }^{58}$.

Presentadas algunas de las conclusiones del estudio, vamos a aplicarlas a los planes y programas que inspiran las campañas que estamos contemplando. El I Plan de Acción contra la Violencia Doméstica nació con el objetivo, por una parte, de reducir, en primera instancia, y erradicar, finalmente, los actos violentos en el seno de las familias $y$, por otra, de arbitrar los medios necesarios para paliar sus efectos en las víctimas ${ }^{59}$. Estimamos que, de esta forma, ya está ausente el planteamiento de la desigualdad entre hombres y mujeres en la sociedad, pues se está encasillando la violencia en el ámbito familiar y, por tanto, considerándola como un asunto privado y no social.

Esta afirmación se ratifica con lo expuesto en la evaluación de este I Plan ${ }^{60}$, en la que se pone de manifiesto que las medidas adoptadas en base a los principios descritos, tienen una pretensión asistencial y paliativa, antes que preventiva. Asimismo, se expone que las mujeres que denuncian malos tratos todavía no reciben la asistencia y la protección necesaria, y que perciben una ayuda paliativa que las favorece a salir de las situaciones más enconadas de violencia, pero que más tarde no les ofrece alternativas operativas para rehacer sus vidas con autonomía personal e independencia económica.

Por todo ello, no sorprende que los mensajes de las campañas que se configuraron siguiendo este Plan insistan en la denuncia, informen de los servicios disponibles de asistencia y eludan totalmente la prevención. Tampoco que no aparezca el componente de empoderamiento de las víctimas, sino el tratamiento de los síntomas, que tienen que ver con las consecuencias de una violencia exclusivamente física.

56. Ibíd., p. 74.

57. Ibíd., p. 75

58. Ibíd., p. 77.

59. Según se recoge en la Introducción del II Plan Integral contra la Violencia Doméstica.

60. Evaluación del I Plan de Acción Contra la Violencia Doméstica elaborada en 2001 por IMOP Encuestas que comprende grupos de discusión y entrevistas en profundidad. 
El II Plan Integral contra la Violencia Doméstica incluye en su introducción una serie de principios que permitirían situarlo en el primer marco «De igualdad de género». En dicho preámbulo establece que "las políticas de igualdad de oportunidades entre hombres y mujeres deben considerar la violencia doméstica como uno de los ejes básicos de actuación, al constituirse, simultáneamente, como causa y efecto de la discriminación que padecen las mujeres en todos los ámbitos de la vida social y privada».

Asimismo, propone que las medidas de intervención que es preciso poner en marcha tienen que ir encaminadas, fundamentalmente, a erradicar la violencia, mediante la prevención de los actos violentos, a través de una educación basada en la igualdad y no discriminación por razón de sexo; a sancionar las conductas violentas, como otra forma preventiva por su fuerza persuasiva; y a paliar los efectos que los actos violentos producen en las víctimas ${ }^{61}$.

Sin embargo, las dos campañas que se promovieron dentro de esta normativa parecen ajustarse sobre todo al último propósito, por lo que a pesar de las intenciones expuestas, si atendemos a las soluciones este plan encajaría mejor en el segundo marco antes definido. Pues aunque son muy diferentes entre sí62, finalmente sus intenciones siguen siendo paliativas, insistiendo de nuevo en la denuncia, en los servicios de atención y en los guiños de apoyo. Es justo decir a su vez que el segundo anuncio interpela a las mujeres recordándoles que tienen derechos y dignidad, mensaje que iría más en la línea del empoderamiento. No obstante, y a pesar también de que ésta cambia de imagen y rescata los malos tratos de la oscuridad y de los golpes físicos en el ámbito doméstico, la conclusión viene a ser que la mujer no está sola, y que el resto de la sociedad, y la institución en concreto, no le van a ayudar a empoderarse, sino a prestarla asistencia. Siempre y cuando ella ponga en marcha la maquinaria asistencial y denuncie.

El estudio observa una mudanza hacia el primer marco -de igualdad de género- a partir de la aprobación de la Ley Integral. Su artículo 1 define violencia de género como: "la violencia que, como manifestación de la discriminación, la situación de desigualdad y las relaciones de poder de los hombres sobre las mujeres, se ejerce sobre éstas por parte de quienes sean o hayan sido sus cónyuges o de quienes estén o hayan estado ligados a ellas por relaciones similares de afectividad, aun sin convivencia».

El artículo 18 garantiza el derecho de las mujeres víctimas de violencia de género a recibir plena información y asesoramiento adecuado a su situación personal, a través de los servicios, organismos u oficinas que puedan disponer las Administraciones Públicas. "Dicha información comprenderá las medidas contempladas en la ley relativas a su protección y seguridad, y los derechos y ayudas previstos en la misma».

61. Subrayado nuestro.

62. Como ya ha quedado explicado, una sigue instando a la llamada por teléfono y la otra da un mensaje de aliento a través de otras mujeres. 
Las campañas que han surgido en este escenario, si bien demuestran un cambio de talante, se ajustan más a lo expuesto en el artículo sobre las medidas -el 18- que a los principios manifestados en el comienzo de la ley. También en este caso hay que hacer la salvedad de la escenificación de la publicidad con el lema "Gana la ley», en la que por primera vez la mujer no tiene señales físicas de maltrato, no llora, gime ni se lamenta, y sale del hogar para ir a un juzgado. Pero la campaña que anuncia el 016 vuelve a colocar en el centro la muerte, el sollozo, la impotencia, el teléfono, la asistencia... De nuevo se insta a cortar a tiempo, a denunciar, a zanjar el silencio.

En lo que respecta a la Comunidad de Madrid, la campaña que hemos mencionado tiene como marco la Ley Integral contra la Violencia de Género aprobada por esta autonomía en diciembre de 2005. En su preámbulo, entiende que la violencia de género es un obstáculo para el desarrollo de una sociedad democrática, una manifestación de las desigualdades entre hombres y mujeres que afecta no sólo a la integridad física de las mujeres, sino también a su dignidad. Dicha ley manifiesta como objeto prevenir y combatir la violencia de género así como garantizar la asistencia y protección de las víctimas con medidas de carácter integral.

Este compendio de principios trascienden de alguna manera a través del anuncio expuesto, que asimila el maltrato a la humillación; y de otros spot de la misma campaña, como el que presenta a una mujer declarando que su ex pareja ya no la asusta con su mirada, o aquél en el que un joven, al ser preguntado por su padre -supuesto maltratador-, elude la contestación y prefiere recordar que su madre vuelve a sonreír. Sin embargo, ¿alude a una atención integral el colofón de estas campañas, que cierran con un número de teléfono y los servicios disponibles para asistir a las mujeres y a sus hijos e hijas? Creemos que no.

A modo de conclusión podemos afirmar que si atendemos a las gramáticas de la publicidad institucional con todo lo hasta ahora expuesto, se detecta que es persistente el modelo asistencial y proclive a que las mujeres denuncien. Pues aunque los principios de las normas que impulsan estas campañas consideren que la violencia es causa y consecuencia de la desigualdad entre hombres y mujeres, y que es precisa la recuperación integral de ellas -lo cual ni siquiera es común en todas-, los mensajes siguen incidiendo en su protección y refugio en las instituciones y no tanto en potenciar su confianza e independencia. De esta forma, queda claro que se victimiza a las mujeres, y que por tanto el mensaje contra la violencia se vuelve contra su principal destinatario -las mujeres maltratadas- ejerciendo contra él violencia simbólica.

\section{NOSOTR@S, ASISTENTES; LAS OTRAS, VÍCTIMAS}

La forma de representar a las mujeres y la violencia de género que hemos observado hasta el momento nos lleva a realizar otra afirmación. Y es que las directrices que siguen las campañas están contribuyendo a levantar una barrera entre un nosotr@s no maltratad@s y unas otras -de ojos morados o sonrisas serenas-, extrañas, opacas y vulnerables a las que hay que proteger. Extrañas por diferentes, porque a ellas les ocurre algo que no pasa al resto de la sociedad y 
de lo que no saben salir por sí mismas: son víctimas. Opacas porque se hacen invisibles cuando no son violentadas, o cuando también lo son, como es el caso de las maltratadas psíquicamente. Y vulnerables, porque ante todo, precisan amparo y resguardo. En la otra parte estaría el resto de la sociedad, y en especial las instituciones, tejiendo unas redes asistenciales para ayudar a las otras en las que paradójicamente pueden quedar atrapadas.

\subsection{Las otras}

¿Qué dicen las receptoras reales de los textos publicitarios que las construyen como las otras? Como avanzamos al principio, vamos a detenernos un momento en recoger algunas de las lecturas que las mujeres maltratadas realizan de los discursos de la publicidad institucional extraídos a través de entrevistas en profundidad.

En primer lugar, queremos poner de manifiesto algunas cuestiones relevantes sobre su percepción de las campañas. Por ejemplo, que las primeras resultan más impactantes para las que padecen o han padecido violencia física; mientras que las sometidas a malos tratos psíquicos dicen no sentirse reconocidas en la imagen de una mujer golpeada porque invisibiliza una violencia más silenciosa, que al contrastarla con los golpes y los moretones les hace sentirla como inexistente o menor.

Es reseñable también que varias de las entrevistadas, por el momento en el que se encontraban -bien convivían con su pareja o estaba muy reciente la separación- se negaran a ver las campañas, mostraran éstas más o menos violencia. No obstante, las nuevas campañas son, en opinión de algunas, demasiado light.

Lo que es coincidente en los casos en los que sí las visionaron, es que la que más las conmueve es la publicidad que difundió en 2000 el Instituto de la Mujer en la que el protagonista es un niño que susurra y da consuelo a su madre tendida en el suelo e inmóvil con muestras de haber sido golpeada, ya que creen que si no rompen por sí mismas, el hecho de recordarlas que sus hijas e hijos, como el del anuncio, están sufriendo, puede inducirlas a reaccionar.

También es la publicidad más controvertida para algunas de las y los jóvenes universitarios entrevistados. Es la que más impresionó a la mayoría, sobre todo por su capacidad de alertar sobre las repercusiones que también tiene esta violencia para los hijos e hijas.

Vayamos ahora a sus propios testimonios. Arrancamos con algunos apuntes sobre el mensaje que lanzan las campañas a las mujeres que sufren violencia apremiándolas a acabar con el silencio, a llamar por teléfono y a denunciar. El problema, dicen ellas, es que tras la denuncia comienza un trayecto difícil y muy arriesgado, sobre todo porque tienen que volver a su domicilio, donde reside el maltratador:

"Llamé al teléfono de emergencia de malos tratos y me dijeron que tenía que denunciar. Y yo les dije 'sí, yo denuncio, pero primero sáquenme de aquí'. Y nada. Yo tenía claro que si denunciaba no volvía a mi casa». (38 años, separada, 2 hijas). 
"Ya sabemos que hay teléfonos de ayuda, sitios donde ir, pero yo me imagino a esa mujer con el teléfono en la mano -en alusión a una de las campañas- llamando a una asociación o donde sea, y el marido entrar por la puerta y liarse a palos con ella, porque esto ha sucedido». (60 años, casada, 4 hijos/as).

Se apoyan también en el hecho de que no son tantos recursos como los publicitados los que se ofrecen a las mujeres después de denunciar:

"Que den tanto bombo con que denuncies, que hagas, que tienes salida... pero una vez que estás fuera, tienes pocos recursos». (38 años, separada, 2 hijas).

"Te tendrían que decir qué te vas a encontrar detrás de ese teléfono». (37 años, casada, sin hijos).

"Te dan un número, te dicen vale llama, tienes otra vida, tienes tus derechos, pero realmente tampoco sabes a lo que te vas a enfrentar, y realmente hay muchas mujeres que han realizado esa llamada y luego al muy poco tiempo, unos días, se han visto totalmente desprotegidas». (55 años, divorciada, 2 hijos/as).

La representación de la mujer maltratada como agredida físicamente no favorece la identificación de las receptoras, especialmente las que han sufrido o sufren violencia psicológica, lo cual redunda en una menor efectividad de las campañas.

«La imagen de una persona agredida o con dificultades y problemas llamando por teléfono, no me identifico con ella». (35 años, casada, 2 hijos/as).

"Como que ves muy fuerte eso -las agresiones físicas-y piensas, pues lo mío no es tan fuerte. Lo que a mí me está pasando pues será normal, porque a mí eso no...». (37 años, casada, 1 hijo).

«El maltrato no es solamente que te agredan, que te dejen tirada en el suelo o que te pongan como un cristo. El maltrato se puede hacer de muchas maneras, también puede ser psicológico. Habría que tratarlo de otra manera». (33 años, casada, 1 hijo).

«Las campañas van dirigidas a los malos tratos físicos, cuando hay un porcentaje muy alto de malos tratos emocionales que son durísimos y esa parte no la contempla ninguna campaña». (55 años, divorciada, 2 hijos/as).

¿Cuáles son, entonces, sus propuestas? Podemos observar que apuntan en varias direcciones.

Algunas plantean lanzar mensajes que muevan a las mujeres para que sean conscientes de los malos tratos:

«Hay muchas veces que nosotras mismas nos engañamos. Y habría que hacer una campaña que nos quitara la tapadera de los ojos». (33 años, casada, 1 hijo).

"Creo que deberían enfocar las cosas desde el principio, cuando empiezan a faltar el respeto con hechos y con palabras: 'no permitas lo más mínimo'». (40 años, separada, 4 hijos).

Para que esto sea posible, manifiestan que sería necesario salirse del estereotipo de mujer golpeada y emplear modelos de mujeres "normales», que escenifiquen rituales similares a los que viven ellas en sus relaciones de pareja:

"Ver a una persona normal, no verte con el ojo morado. En una circunstancia normal, tomando un café y diciéndole a la amiga 'me está maltratando, me está 
agrediendo'. O (...) contando pequeñas cosas, 'anoche él llegó molesto porque llegó tomado y entonces yo no le serví la cena y él se molestó'. Justificándote un poco, que es lo que siempre hacemos». (32 años, separada, 1 hija).

«Creo que tendrían que ser más gráficas. (...) Te tiene que aparecer algo, que tú consideras que es normal o que está dentro de la normalidad, y que no lo es. Y que nadie te ha dicho que no lo es. (...) Algo como que a lo mejor estés con un grupo de amigos y tú vayas a decir 'oye, sí, no, pues yo opino esto' y coja el de turno y te diga 'tú cállate, que tú no sabes nada de esto'». (55 años, divorciada, 2 hijos/as).

Asimismo, muchas se declaran impactadas por la campaña del Instituto de la Mujer en la que se recurre a la imagen de un niño consolando a su madre. Consideran que ese sí puede ser un impulso para reaccionar:

"Creo que la -campaña- más impactante para salir es la del niño. Creo que toda madre se lo pensaría dos veces el soportar eso, si ve el daño que se le está haciendo al niño». (44 años, divorciada, 3 hijos/as).

«El -anuncio- del niño es muy duro, a mí es el que más me impresiona y el que más me duele, porque además cuando mi pareja me agredió estaba mi hijo presente». (55 años, separada, 2 hijos).

"A mí me llegó en su día la del niño que está la madre en el suelo. No sé, a lo mejor la que en ese momento más me impactó como madre». (55 años, divorciada, 2 hijos/as). ción.

En algún caso, sugieren que más que campañas, se apueste por la educa-

«La educación en igualdad me parece lo más acertado, pero ¿se está haciendo de verdad?». (37 años, casada, sin hijos).

También apoyan aquellos anuncios en los que trasciende que la institución está para ayudarlas.

«Este -anuncio, el de las mujeres famosas- lo veo muy bonito, muy solidario, como que hay alguien ahí que se preocupa». (34 años, separada, 1 hija).

"Estamos aquí para ayudarte, estamos aquí para... te entendemos, sabemos lo que te está pasando', son mensajes que desde luego son esperanzadores». (55 años, separada, 2 hijos).

«Estas son las frases que me hubiera gustado oír: 'Quiero que sepas que estamos contigo', 'que tú no eres la culpable', 'soy consciente del porqué de tu silencio'». (40 años, separada, 3 hijos).

En algunos de sus discursos, plantean iniciativas que abogan por su empoderamiento:

"Tú ya no eres víctima porque has salido de ello. Y como has salido de ello, ahora lo que tienes que coger es la carretilla, a lo mejor que te puedan ayudar a coger la carretilla y seguir el camino, o su peso que todavía no puedas llevarlo. Pero llega un momento que hasta tú debes llevar la carretilla sola también». (43 años, separada, 4 hijos/as).

"Cuando tú aguantas los malos tratos, si no reaccionas pierdes la dignidad, y la dignidad es lo último que se puede perder porque si tú no tienes ese sentimiento, pues... estás perdida, estás muerta realmente». (55 años, separada, 2 hijos). 
"Si yo ahora tuviera que ayudar a otra persona, no podría hacerlo, porque tendría que decirle 'te tienes que ayudar tú misma', hasta que tú no veas la realidad, te veas en el espejo y digas 'me está maltratando', es que no hay otra fuerza, no hay otro medio, no hay otra persona». (32 años, separada, 1 hija).

"Cuanto más sencillo sea- un anuncio- es más cercano. Y lo más sencillo es una mujer dirigiéndose a otra mujer diciéndole: 'tú vales mucho, tienes un papel importantísimo en la sociedad'». (60 años, casada, 4 hijos/as).

No podemos olvidarnos, no obstante, de aquellas mujeres, cinco de las entrevistadas, que prefirieron no ver las campañas.

«No quiero verlo. No puedo, lo siento. No, porque me veo yo ahí y no puedo, no puedo. (...) Me ayudan a hundirme más, no, no puedo ver a una mujer así -golpeada- porque si la viese y se hiciera justicia, pues diría bueno, vale la pena. Pero hasta ahora no se está haciendo». (40 años, separada, 1 hija).

\subsection{Nosotr@s}

Desde el otro lado del muro, las campañas se componen y se observan de forma diferente. Presentamos tan sólo unas pinceladas de las opiniones de 25 jóvenes universitarios de entre 18 y 21 años que fueron encuestados sobre los anuncios.

Las preferencias oscilan sobre todo entre la campaña del niño y la de las mujeres famosas:

«Creo que muchas mujeres no denuncian por sus hijos, y el mostrar una escena como esa puede concienciarlas de que ellos también lo sufren». (Mujer, 18 años).

"-Me agrada más el anuncio- en el que salen las mujeres intentando hacer ver a la mujer maltratada que no está sola, porque, así, esa persona se puede sentir apoyada». (Mujer, 18 años).

Y aunque varios se decantan por las campañas que ya existen, sus propuestas, siendo muy variadas, podrían agruparse en cuatro tendencias, las que se destilan de estos enunciados:

"Una campaña impactante, y que dé ánimos para denunciarla -la violencia-y acabar con ella». (Mujer, 18 años).

"Lo importante de las campañas es asegurar la seguridad de la mujer e implicar a la población». (Mujer, 18 años).

"Creo que los anuncios se deberían enfocar hacia los hombres, para concienciarles de que el maltrato no lleva a nada. Si los hombres no pegan, las mujeres no tendrían que denunciar». (Hombre, 18 años).

"Las campañas en las que se intente concienciar a la mujer lo que vale y que no se merece tales tratos por parte de un hombre. También en las que se conciencie al hombre desde su juventud que la igualdad entre hombres y mujeres jexiste!». (Mujer, 18 años).

\section{CONCLUSIONES}

A tenor de todo lo expuesto y de lo que nos ha permitido airear de lo oculto de los textos el análisis de sus gramáticas, podemos afirmar que los planteamientos que realizábamos al principio del artículo iban bien encaminados. Por un lado, 
hemos comprobado que las campañas con las que las instituciones pretenden luchar contra la violencia de género siguen planteando los mismos temas desde que comenzaron a utilizar este recurso hasta la actualidad. Es decir: lejos de suscitar verdaderas alternativas para las mujeres, como podría ser el impulso de su empoderamiento, mantienen el alegato de la protección y el refugio a través de los textos visuales y verbales de la publicidad. Tal vez porque, entre otros factores, hay un fuerte desajuste entre las filosofías de los planes que impulsan las campañas -que sí atienden más a la desigualdad que genera la violencia y a la necesidad de acabar con ella-, y las verdaderas iniciativas. Lo estudiado también nos lleva a ratificar que ese discurso victimiza a las mujeres, porque por un lado las culpabiliza y pone en sus manos la ruptura de la situación a través de la denuncia; y por otro las sobreprotege, de tal forma que su mensaje difunde la idea de que todos los pasos que vengan después tienen que darse bajo el amparo de las instituciones. Por tanto, y como "profecía autocumplida» ${ }^{63}$, el discurso para frenar la violencia acaba ejerciendo violencia simbólica contra las propias afectadas. Una violencia que también se genera a través de la discriminación y la negación del otro y que promueve la búsqueda de "la comunidad de un 'nosotros' fuerte y cohesionado» ${ }^{64}$. Precisamente las representaciones a las que se recurre en esta publicidad están cimentando un muro entre las que el texto construye como víctimas -las otras-, y como protectores -el resto de la sociedad $y$ en especial las instituciones-.

Justamente, la lectura que hacen las mujeres reales sobre estos discursos delata que la asistencialidad está vacía y que se queda muchas veces sólo en el mensaje. No obstante, y aunque reclaman un cambio, siguen pidiendo no tanto su empoderamiento, que también, sino asimismo, una ayuda que vendría por los mismos cauces; y es que, como plantea Bourdieu, «el poder simbólico no puede ejercerse sin la contribución de los que lo soportan porque lo construyen como tal» ${ }^{65}$.

Por su parte, los jóvenes apuntan hacia otro lado, como puede ser la concienciación de la mujer sobre «lo que vale y que no se merece tales tratos por parte de un hombre».

El artículo deja así abierta la posibilidad a seguir indagando en otros discursos de las instituciones sobre la violencia que puedan estar también victimizando a las mujeres; a darles voz, además de a otro tipo de públicos, para que opinen sobre estas medidas; y a plantear alternativas a los mensajes que hasta ahora han prevalecido por parte de la administración en este campo.

63. Según la expresión acuñada por Merton, que en el libro de B. Muñoz se utiliza para referirse al hecho de que la mujer puede llegar a adaptarse a su imagen estereotipada no sólo a fuerza de escucharla, sino también a base de ser tratada como si la imagen fuera verdadera, en MUÑOZ, Blanca (coord): op. cit.

64. Peñamarín, Cristina, "La violencia en...», op. cit.

65. Bourdieu, Pierre: La dominación..., op. cit., p. 56. 


\section{BIBLIOGRAFÍA}

ALTÉS, Elvira: "¿Cómo funcionan y para que sirven los estereotipos en los medios de comunicación?», en www.bizkaia.net/Home2/Archivos/DPTO1/Noticias/ Adjuntos/297_mujeres.jornadas03.Ponencias.doc.

BENGOECHEA, Mercedes: «En el umbral de un nuevo discurso periodístico sobre violencia y agencia femenina: de la crónica de sucesos a la reseña literaria», Cuadernos de Información y Comunicación, 5 (2000), pp. 9-22.

BOURDIEU, Pierre: Sobre la televisión, Barcelona, Anagrama, 1997.

BOURDIEU, Pierre: La dominación masculina, Barcelona, Anagrama, 2007.

Bustelo, María y LombARDo, Emanuela (eds): Políticas de igualdad en España y en Europa, Madrid, Cátedra, 2007.

Bustelo, María; LóPez, Silvia y Platero, Raquel: "La representación de la violencia contra las mujeres como un asunto de género y un problema público en España", en M. Bustelo y E. Lombardo (eds.): Políticas de igualdad en España y en Europa, Madrid, Cátedra, 2007, pp. 67-97.

GOFFMAN, Erving: Los momentos y sus hombres, Barcelona, Paidós, 1991.

GRANDI, Roberto: Texto y contexto en los medios de comunicación, Barcelona, Bosch, 1995.

IMBERT, Gérard: Los escenarios de la violencia, Barcelona, Icaria, 1992.

IRANZO, Patricia I.: «Estereotipos publicitarios y violencia racial», Trípodos, número extra (2003), pp. 705-718.

JUARISTI, P.: "Origen, recorrido y futuro de la comisión asesora de publicidad no sexista y género. Begira», en: www.bizkaia.net/Home2/Archivos/DPTO1/Noticias/ Adjuntos/297_mujeres.jornadas03.Ponencias.doc.

LEÓN, José Luís: Los efectos de la publicidad, Barcelona, Ariel, 1996.

LÓPEZ DíEZ, Pilar: "La violencia contra las mujeres en los medios de comunicación», en P. López Díez: Mujer, violencia y medios de comunicación, Madrid, Instituto Oficial de RTVE, Ministerio de Trabajo y Asuntos Sociales, 2002, pp. 21-34.

LozAno, Jorge; Peñamarín, Cristina y ABril, Gonzalo: Análisis del discurso. Hacia una semiótica de la interacción textual, Madrid, Cátedra, 1999.

LLEDÓ, Eulàlia: Cómo tratar bien a los malos tratos, Sevilla, Instituto Andaluz de la Mujer, 1999.

MARTín SerRano, Manuel: Nosotras y vosotros según nos ve la televisión, Madrid, Instituto de la Mujer, 1995.

MARTínEZ, Inmaculada: "La mujer y la publicidad en España: contradicciones sociales y discursivas", en www.razonypalabra.org.mx/libros/libros/mujerypublicidad.pdf.

MUÑoz, Blanca (coord): Medios de comunicación, mujeres y cambio cultural, Madrid, Dirección General de la Mujer, Comunidad de Madrid, 2001.

NaVArro, Amparo y VeGA, Cristina: Mediaciones y traslaciones. Gramáticas visuales de la violencia machista en la universidad, Madrid, Traficantes de sueños, 2007.

PeÑAMARÍN, Cristina y FABRETTI, Carlo: La mujer en la publicidad, Madrid, Instituto de la Mujer, 1990.

PeÑAMARÍN, Cristina: “¿Qué puede mostrar el análisis de textos? Discursos e imágenes sobre la inmigración en El País», Cuadernos de Información y Comunicación, 3 (1997), pp. $145-166$.

PEÑAMARÍN, Cristina: «Ficción televisiva y pensamiento narrativo», Semiosfera, 11, (2002), www.uc3m.es/uc3m/inst/MU/Cristin4.htm

PeÑAmarín, Cristina: «La violencia en las representaciones. Políticas de la indiferencia y la hostilidad», en F. García Selgas y C. Romero Bachiller (eds.): El doble filo de la navaja: violencia y representación, Madrid, Trotta, 2006, pp. 131-144. 
Gramáticas de la publicidad sobre violencia: la ausencia del empoderamiento tras...

Rodrigo Alsina, Miquel: Teorías de la comunicación. Ámbitos, métodos y perspectivas, Barcelona, Castelló de la Plana, València, U. Autònoma de Barcelona, U. Jaume I, U. Pompeu Fabra, U. de València, 2001.

TISSERON, Serge: Internet, videojuegos, televisión, Barcelona, Editorial Grao, 2006.

VALLES, Miguel: Técnicas cualitativas de investigación social. Reflexión metodológica y práctica profesional, Madrid, Síntesis, 1999.

Fecha de recepción: $\quad$ 04-02-2008 Fecha de aceptación: 29-02-2008 